\title{
Learn from Leaders \#2: Getting the Financing Your Venture Needs to Survive
}

\author{
Jon Eckhardt (University of Wisconsin-Madison) \\ Daniel Forbes (University of Minnesota, Carlson School of Management)
}

KEYWORDS: Leadership, Startups, financing.

This is the second video in our exclusive series called "Learn from Leaders," featuring advice for early-stage entrepreneurs and innovators from founders and CEOs of groundbreaking companies. Each of our Learn from Leaders videos focuses on an important step in launching a company. In this one, leaders talk about the harrowing process of finding financing and investors for their new ventures, which went on to become wildly successful.

Our interview subjects include Dick Schulze, founder and former CEO of Best Buy; Linda Hall, former CEO of MinuteClinic; Scott Nash, founder of Mom's Organic Market; Seth Goldman, founder of Honest Tea; Jeff Freeland-Nelson, founder of Yoxo Toys; and Ann Winblad, founding partner of Hummer Winblad Venture Partners.
Learn From Leaders: Conversations with Famous Entrepreneurs (https://soundcloud.com/user-876519212-189256831/s ets/learn-from-leaders)

\section{Video produced by John Buday LEARN MORE}

\section{Explore our "Learn From Leaders" Series} (https://eiexchange.com/content/learn-from-leadersfamous-founders-best-advice-for-new-ventures)

\section{LISTEN}

Listen to our original interviews with each of these leaders and others on our podcast channel on Soundcloud.

Link to video

EIX

(https://soundcloud.com/user-876519212-189256831). 